\title{
Subnational economic complexity analysis: case-study of the Kaliningrad region
}

\author{
Goran Roos ${ }^{1}$, Tatiana E. Drok ${ }^{2}$, Anna Novikova ${ }^{3}$, and Yulia Farafonova ${ }^{2, *}$ \\ ${ }^{1}$ Cranfield University, Cranfield, UK \\ ${ }^{2}$ Immanuel Kant Baltic Federal University, Kaliningrad, Russia \\ ${ }^{3}$ Kaliningrad State Technical University, Kaliningrad, Russia
}

\begin{abstract}
Currently, the economic complexity (EC) theory is of considerable relevance. Developed and rapidly developing countries invest heavily in research and development to increase their products complexity as it brings an economy's competitiveness and revenues to a higher level. The article presents the main results of the 2017-2019 EC analysis of a Russian exclave, the Kaliningrad region, whose trade and production specialization have changed dramatically. The study relies on the data of the Atlas of Economic Complexity, the Federal Customs Service of Russia, the Kaliningrad Regional Customs. It applies the author's method for "cleaning" the data. The key feature of the study is the incorporation of the regional data into the global trade statistics. The analysis reveals general trends towards an increase in capabilities in low complexity products. The paper emphasizes that the regional government needs to pursue an active sectoral policy aimed at increasing the economic complexity.
\end{abstract}

\section{Introduction}

According to the UN 2030 Agenda, sustainable development implies the balance between social, economic and environmental spheres. One of the ways to achieve this balance is to increase the economic complexity (EC) of a country or a region [1]. According to studies, it is accompanied by reduced air pollution [2,3], decreased economic inequality [4,5] and increased human development [6], all of which is in line with the UN sustainable development goals.

However, most studies on economic complexity are conducted at the national level, which primarily stems from the availability of trade statistics. In recent years, there have been works on subnational economic complexity (for example, $[7,8,9,10]$ ), however, it is not always possible to apply the methods they propose to regions in other countries due to national specifics of statistical recordings.

* Corresponding author: ifarafonova@kantiana.ru 


\section{Materials and Methods}

Figure 1 shows the general framework for measuring and assessing changes in subnational economic complexity. The study of foreign trade flows of the Kaliningrad region was carried out using the customs statistics of the Federal Customs Service of Russia and the Kaliningrad Regional Customs, which made it possible to combine international and interregional export data. The exclave position of the region results in a high level of openness of the economy comparing to the other regions of Russia [11]. In 2019, it exceeded the average regional level 10 -fold. The key issue in preparing data for the EC analysis is "cleaning" them, i.e. processing both exports and imports data to exclude commodity flows that are not related to the result of the region's economy. These are, first of all, re-export flows, i.e. the export of foreign goods from the territory of the region, temporary exports, goods that initially entered the region as inter-regional imports, etc. The study covers the period of 2017-2019 since the EC analysis relies on the global trade data with the latest being currently available for 2019 . 


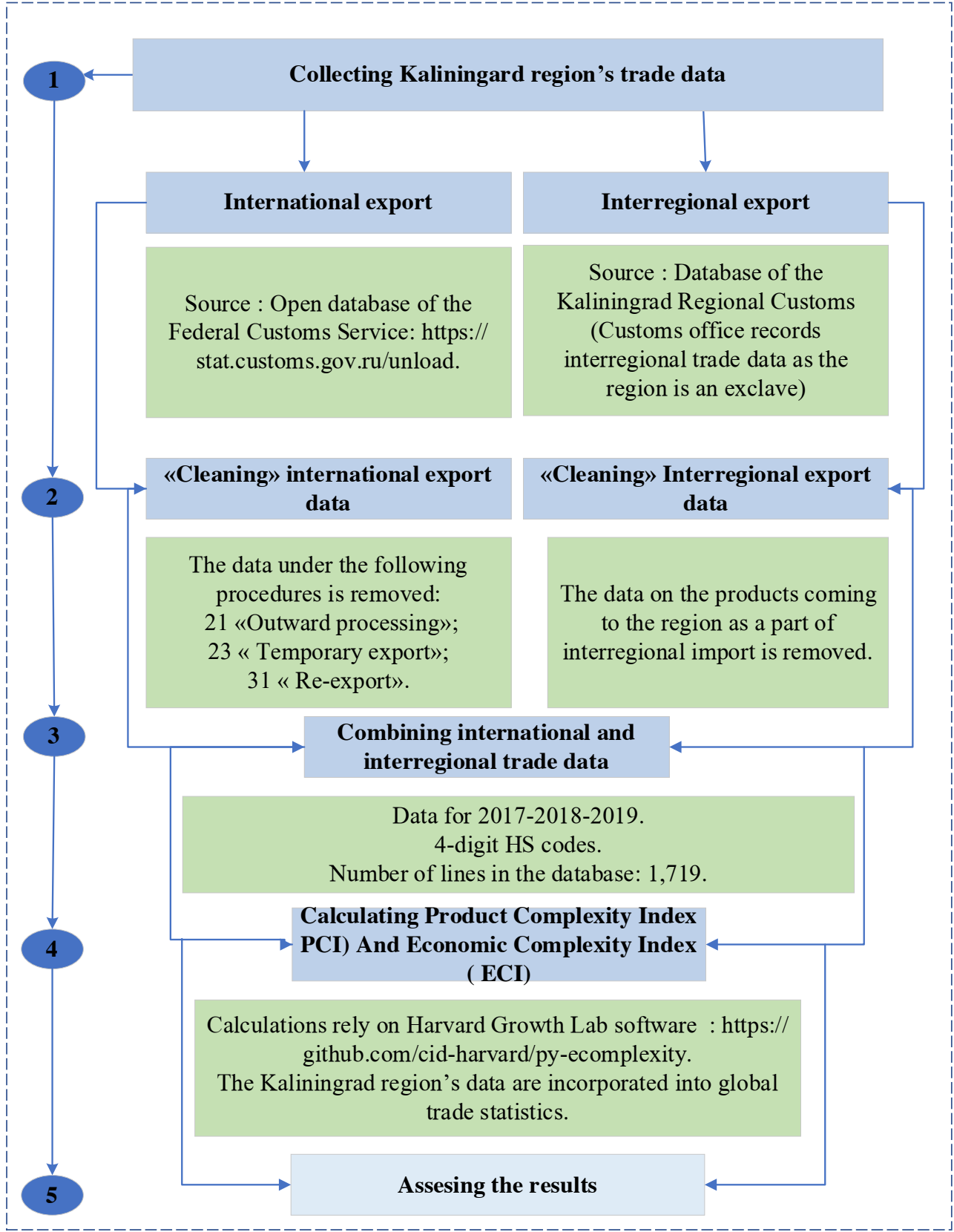

Fig. 1. A structural and logical framework for assessing changes in subnational economic complexity. Source: [12]

Preparing the data for measuring subnational EC level, the authors used their calculations and methodology [13,14], as well as the Harvard Growth Lab software (https:/github.com/cid-harvard/py-ecomplexity), and global trade data of the Atlas of Economic Complexity.

The study applies general scientific research methods (statistical, comparative, descriptive, etc.) and EC analysis methods. 


\section{Results and Discussions}

Table 1 shows the general structure of the combined export of the region for the study period.

Table 1. Commodity structure of the combined export of the region in 2017-2019, \%

\begin{tabular}{|l|l|c|c|c|c|}
\hline $\begin{array}{l}\text { The EAEU } \\
\text { Commodity } \\
\text { Nomenclature } \\
\text { of Foreign } \\
\begin{array}{l}\text { Economic } \\
\text { Activity }\end{array}\end{array}$ & \multicolumn{1}{|c|}{ Name } & 2017 & 2018 & 2019 & $\begin{array}{c}2017- \\
2019 \\
\text { changes }\end{array}$ \\
\hline $01-24$ & $\begin{array}{l}\text { Food products and agricultural } \\
\text { raw materials (except textiles) }\end{array}$ & 29 & 24 & 30 & 1 \\
\hline $25-27$ & Mineral products & 1 & 0 & 0 & -1 \\
\hline $28 / 40$ & Chemical products, rubber & 1 & 1 & 4 & 3 \\
\hline $41-43$ & $\begin{array}{l}\text { Raw hides, skins, furs and articles } \\
\text { thereof }\end{array}$ & 0 & 0 & 0 & 0 \\
\hline $44-49$. & Wood, pulp, paper & 1 & 1 & 2 & 1 \\
\hline $50-67$ & Textiles, textile articles, footwear & 0 & 0 & 1 & 1 \\
\hline $68-71,91-97$ & Other articles & 1 & 0 & 2 & 1 \\
\hline $72-83$ & Base metals and articles thereof & 2 & 2 & 3 & 1 \\
\hline $84-90$ & Machinery, appliances, vehicles & 65 & 71 & 59 & -6 \\
\hline
\end{tabular}

Source: Authors' calculations

The combined export of the region was formed mainly by the groups "84-90" and "01$24 "$. The largest share of groups "84-90" in the export structure was recorded in 2018. The data analysis indicates a low degree of export diversification.

The use of the Harvard Growth Lab software to process "cleaned" aggregate export data allowed us to assess the changes in the level of economic and product complexity of the region (Tab.2).

Table 2. General EC analysis of the Kaliningrad region, 2017-2019

\begin{tabular}{|c|c|c|c|c|c|c|}
\hline & & \multicolumn{5}{|c|}{ Export volume weighted } \\
\cline { 3 - 7 } Year & $\begin{array}{c}\text { Economic } \\
\text { Complexity } \\
\text { Index (ECI) }\end{array}$ & $\begin{array}{c}\text { Product } \\
\text { Complexity } \\
\text { Index (PCI) }\end{array}$ & Density & $\begin{array}{c}\text { Complexity } \\
\text { Outlook } \\
\text { Index } \\
\text { (COI) }\end{array}$ & $\begin{array}{c}\text { Complexity } \\
\text { Outlook } \\
\text { Gain (COG) }\end{array}$ & $\begin{array}{c}\text { Revealed } \\
\text { Comparative } \\
\text { Advantage } \\
\text { (RCA) }\end{array}$ \\
\hline 2017 & 0.22 & 1.56 & 1.43 & -0.27 & 0.01 & 24.18 \\
\hline 2018 & 0.22 & 1.73 & 2.94 & 0.16 & 0.01 & 19.61 \\
\hline 2019 & 0.33 & 1.40 & 3.36 & 0.10 & 0.03 & 17.52 \\
\hline Trend & Positive & Negative & Positive & Positive & Positive & Negative \\
\hline
\end{tabular}

Source: Authors' calculations

There are 158 product categories for which the data are available for 2017 - 2019. Table

3 provides a visual representation of the development for these categories. 
Table 1. PCI for the Kaliningrad region's exports in 2017 - 2019

\begin{tabular}{|l|l|l|}
\hline Change trajectory & \multicolumn{1}{|c|}{ Increased Export Volume } & \multicolumn{1}{c|}{ Decreased Export Volume } \\
\hline Increased PCI & $\begin{array}{l}37 \text { categories } \\
\text { (Net export change of } 884 \mathrm{mln} \text {. USD) }\end{array}$ & $\begin{array}{l}\text { 16 categories } \\
\text { (Net export change of -55 mln. USD) }\end{array}$ \\
\hline Decreased PCI & $\begin{array}{l}79 \text { categories } \\
\text { (Net export change of 2,265 mln.USD) }\end{array}$ & $\begin{array}{l}\text { 26 categories } \\
\text { (Net export change of -627 mln. USD) }\end{array}$ \\
\hline
\end{tabular}

Source: Authors' calculations

An indicator of a sustainably developing economy is a decrease in low PCI products and an increase in high PCI products. In the Kaliningrad region, only $36 \%$ of the export growth is accounted for by the products with an increased PCI, which is not satisfactory. At the same time, there is a $92 \%$ decline in exports of products with a decreasing PCI, which is a positive trend.

The implied capability density has increased for all 158 product categories for which data are available for the entire study period (Table 4). This means that the economy is increasing its capabilities underpinning the products that its exports.

Table 2. Revealed Index of Comparative Advantage (RCA) in 2017 - 2019

\begin{tabular}{|c|l|l|}
\hline Change trajectory & \multicolumn{1}{|c|}{ Increased Export Volume } & \multicolumn{1}{c|}{ Decreased Export Volume } \\
\hline $\begin{array}{l}\text { Increased RCA } \\
\text { of the category }\end{array}$ & $\begin{array}{l}\text { 101 product categories } \\
\text { (Net export change of 2,698 mln. USD) }\end{array}$ & $\begin{array}{l}\text { 7 product categories } \\
\text { (Net export change of -3 mln. USD) }\end{array}$ \\
\hline Decreased RCA & $\begin{array}{l}\text { 15 product categories } \\
\text { (Net export change of 451 mln. USD) }\end{array}$ & $\begin{array}{l}\text { 35 product categories } \\
\text { (Net export change of -680 mln. USD) }\end{array}$ \\
\hline
\end{tabular}

Source: Authors' calculations

Over time, the economy will increase its export performance in product categories where its revealed comparative advantages have increased. Table 4 shows that the net export increase in product categories with increasing RCA is $2,695 \mathrm{mln}$. rub. and the net export decrease in product categories with decreasing RCA is $229 \mathrm{mln}$. rub.

The most desirable categories are those where both PCI and RCA are increasing. These include 8701 "Tractors", 9403 "Furniture and parts thereof", 8309 "Stoppers, caps and lids", 8418 "Refrigerators, freezers and other refrigerating or freezing equipment", 5703 "Carpets and other textile floor coverings", 7308 "Structures and parts of structures of iron or steel", 7326 "Articles of iron or steel", 8413 "Pumps for liquids; liquid elevators; parts thereof", 2923 "Salts and hydroxide", 4814 "Wallpaper", etc.

\section{Conclusions}

Economic complexity analysis is a suitable tool to understand the competitive development of regional economies provided that there is interregional export and import statistics available. The Kaliningrad region's data meet this requirement, thus a subnational economic complexity analysis can be carried out.

Structural changes in an economy normally take some time, however, the three-year analysis allows identifying some general trends. These include the decline in the export volume-weighted product complexity and the export weighted revealed comparative advantage.

Combined with the increase in implied capability density, this indicates that the economy is deepening its capabilities underpinning the export of low complexity products resulting in increased revealed comparative advantage in these product domains. In times of global structural change (greening and digitalisation of the economy), this is not necessarily providing a foundation for success during and after this structural change. 
Given that the smaller an economy, the greater the extent to which market failure becomes its feature, to ensure the future success for the Kaliningrad region, it is essential for the government to conduct an active industry policy. Its aim shall be building capabilities for future and developing competitive export industries in higher complexity products founded in currently exported products and present capabilities (given that economic development is path-dependent).

The analysis indicates that most of the industry policy recommendations presented in the original analysis [14] still stand.

\section{Acknowledgments}

The study was carried out with the financial support of the RFBR and the Government of the Kaliningrad Region within the framework of the scientific project No. 19-410-390002 "Economic Complexity and Sector-Specific Strategy Selection by the regions of Russia in the context of the emerging value creation paradigm, using the case of the Kaliningrad region".

\section{References}

1. D. Ferraz, Fernanda P.S. Falguera, Mariano B. Enzo, D. Hartmann, Sustainability, 13(3), 1265 (2021)

2. O. Neagu, Approach, 11, 4753 (2019)

3. M. Can, G. Gozgor, Sci. Pollut. Res, 24, 16364 (2017)

4. D. Hartmann, MR Guevara, C. Jara-Figueroa, M. Aristarán, CA Hidalgo, World Dev., 93, 75 (2017)

5. Morais M. Bandeira, Sustainability, 13, 23 (2021)

6. D. Ferraz, HF Moralles, JS Campoli, FCR De Oliveira, Gestão Produção, 25, 839 (2018)

7. S.J.P. Balsalobre, C.L. Verduras, J.D. Lanchas, Measuring the Economic Complexity at the sub-national level using international and interregional trade (2017)

8. F. Farra, N. Klos, U. Schober, O. Sigalova, A. Zhukov, European Bank for Reconstruction and Development Working Paper, 155, 46 (2013)

9. JC Chávez, MT Mosqueda, M. Gómez-Zaldívar, Review of Regional Studies , 47(2), 201 (2017)

10. BS Fritz, RA Manduca, The economic complexity of US metropolitan areas. Regional Studies (2021)

11. A.A. Novikova, Geopolitics and ecodynamics in regions, 6(16), 13 (2020)

12. A.I. Pogorletskiy, Current challenges and prospects for international trade system development, 160 (2020)

13. K.Yu. Voloshenko, A.A. Novikova, Regionalistics, 6(6), 127 (2019)

14. G. Roos, K.Yu. Voloshenko, T.E. Drok, Yu.Yu. Farafonova, Balt. Reg., 12(1), 156 (2020) 